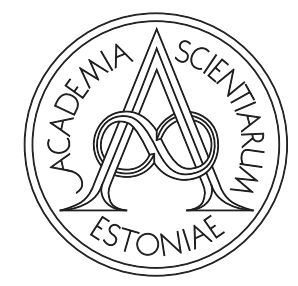

Proceedings of the Estonian Academy of Sciences, $2021,70,4,461-469$

https://doi.org/10.3176/proc.2021.4.13

Available online at www.eap.ee/proceedings

MANUFACTURING

ENGINEERING

\title{
Concept study of sustainable noise control solution for HVAC systems based on microperforated elements
}

\author{
Margus Villau*, Hans Rämmal and Jüri Lavrentjev \\ Department of Mechanical and Industrial Engineering, Tallinn University of Technology, Ehitajate tee 5, 19086 Tallinn, Estonia
}

Received 15 June 2021, accepted 13 July 2021, available online 7 November 2021

(C) 2021 Authors. This is an Open Access article distributed under the terms and conditions of the Creative Commons AttributionNonCommercial 4.0 International License (http://creativecommons.org/licenses/by-nc/4.0/).

\begin{abstract}
Recently fibreless solutions have become a trend in the design of sustainable and environmentally friendly duct silencers. In this respect microperforated panels have been proved to provide adequate performance for the substitution of unfavourable fibrous material layers commonly used in mass-produced silencers. This paper presents an acoustic study of microperforated elements aimed for effective and eco-friendly noise control solutions. Several microperforated sheet metal panels have been experimentally tested in a variety of layered configurations to maximize the sound absorption coefficient in the expected operational frequency range. The optimal solutions have been implemented in the design of novel fibreless solutions, presented in this research, and compared with typical fibrous material filled units commercially available. The results of the study demonstrate the appropriateness of the doublelayered microperforates for a duct silencer application as well as for a variety of NVH (noise, vibration, and harshness) implementations where potent noise absorption is aimed for.
\end{abstract}

Key words: microperforated element, noise control, fibreless, transmission loss, insertion loss, absorption coefficient, HVAC (heating, ventilation, and air conditioning).

\section{INTRODUCTION}

Noise control devices have been extensively used in various technical fields: e.g., automotive and aeronautical industries, construction engineering, HVAC systems, etc. In the recent decade, a requirement for eco-friendly noise cancellation materials in flow ducts replacing fibrous material has become a trend. Being cost-effective and with relatively good sound attenuation properties, the fibrous materials used in current silencers are generally unfavoured. Due to the relocation, contamination and moisturising of the fibrous material, the acoustic performance deteriorates in use when exposed to pulsating media flow.

One of the proposed materials with great potential is a microperforated element, typically provided in sheet metal panels. A variety of microperforated panels (MPPs)

\footnotetext{
${ }^{*}$ Corresponding author, margus.villau@taltech.ee
}

have been widely applied for almost two decades, first introduced by Maa already in the 1970s [1-3]. Maa proposed that the perforations should be reduced to the submillimetre level to provide sufficient acoustic resistance. Analytical models were also developed for the prediction of acoustical properties (equivalent to electrical circuit model). It was highlighted that the MPPs can be tuned for a wide frequency band, thus being suitable for a variety of applications.

The properties and applications of the MPP have also been studied extensively in the TalTech laboratory of technical acoustics [4-6], whereby several different MPPs have been studied with varying aperture geometry and patterns as well as with porosity variations [7]. Additionally, the authors have carried out the first known experimental investigations on the endurance and reliability issues including contamination of the microperforated tube sections in operating internal combustion engine applications [8-9]. 
The current study focuses on the experimental determination of the properties of single- and double-layer MPP configurations for implementations in noise control solutions in HVAC silencers. A double-layer MPP layout was investigated also in the past [10]. Since commercially available HVAC silencers are of resistive type, with the use of microperforated elements and expansion chambers, the hybrid solution can be implemented. It means that both reactive and resistive type noise control can be applied in the same silencer by adding more flexibility to tune it for the required frequency range. Similar work was carried out in recent past, where modal filters were proposed for flow ducts [11] and splitter or baffle type silencers for fan noise control [12] using the MPP. This study has focused on investigating opportunities for replacing the fibrous material layers in mass-produced HVAC silencers with the MPP to achieve an acoustically effective, fibreless, eco-friendly, and sustainable silencer concept.

\section{EXPERIMENTAL STUDIES}

In this paper the experimental studies have been divided into three sections:

1. the impedance tube test for the initial determination of the selected material's acoustical performance, e.g., sound absorption. Secondly, to investigate double-layer layout of microperforated panels and its effect on the absorption coefficient in a frequency range of interest.

2. measurements of transmission loss for several conceptual silencer layouts implementing microperfo- rated materials and optimized solutions using doublelayered configurations.

3. finally, the determination of the insertion loss characteristics of the proposed HVAC silencer layout including a comparison with a market average.

The experimental studies were carried out in the TalTech laboratory of technical acoustics. The key parameters of the silencer elements were acoustically determined by using dedicated test facilities described in the following sub-sections.

\subsection{Materials studied}

One of the aims in this study was the determination of the sound absorption performance characteristics in a variety of layouts of two different commercially available MPP materials. A third MPP material sample was additionally included for reference purposes. The tested materials are presented in Fig. 1. Materials A and B are commercially available under the brand name Acustimet ${ }^{\circledR}$ produced by the Swedish company Sontech International AB [13], the third specimen is a custom-made microperforated panel. The characteristic parameters for the materials studied are shown in Table 1.

Microscopy was performed for materials A and B (see Fig. 2) to determine the aperture geometry and porosity. As we can observe in Fig. 2, materials A and B can be characterized by slit type apertures.

Both material samples, A and B, were manufactured of aluminium alloy whereas the third material $\mathrm{C}$ was made of steel alloy. If the application requires, materials $\mathrm{A}$ and

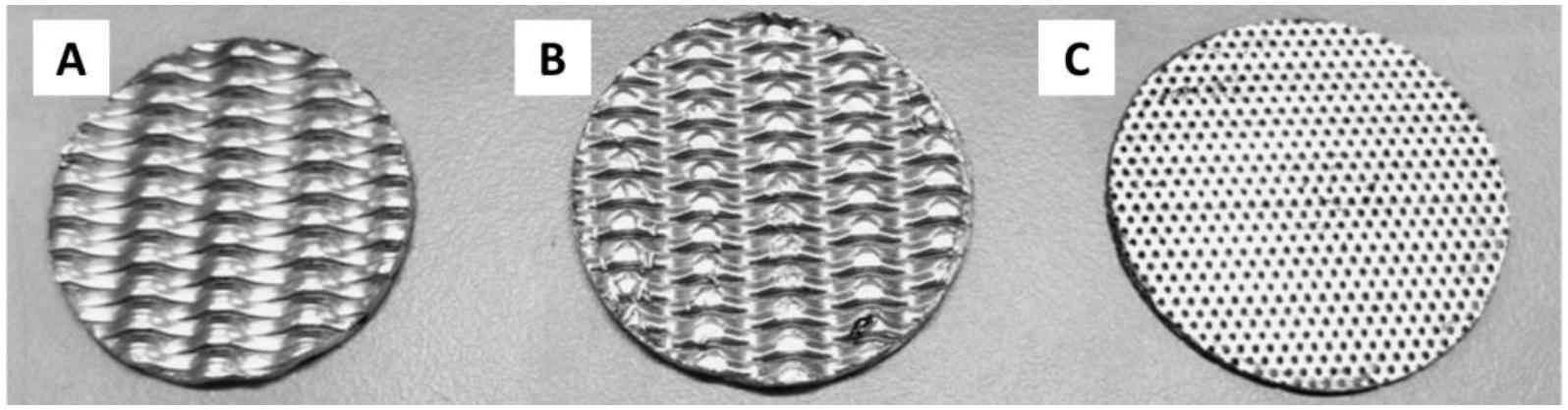

Fig. 1. Material samples $(\mathrm{d}=28 \mathrm{~mm})$ tested: material A; material $\mathrm{B}$; material C.

Table 1. Properties of tested materials

\begin{tabular}{lccc}
\hline & Material A & Material B & Material C \\
\hline Aperture dimensions & $1.7 \times 0.1 \mathrm{~mm}$ & $4 \times 0.1 \mathrm{~mm}$ & $\varnothing 0.5 \mathrm{~mm}$ \\
Aperture shape & Slit shape & Slit shape & Orifice \\
Material used & Aluminium alloy & Aluminium alloy & Steel alloy \\
Specific weight & $2.6 \mathrm{~kg} / \mathrm{m}^{2}$ & $1.67 \mathrm{~kg} / \mathrm{m}^{2}$ & $3.54 \mathrm{~kg} / \mathrm{m}^{2}$ \\
Porosity & $\sim 1 \%$ & $\sim 3 \%$ & $\sim 18 \%$
\end{tabular}



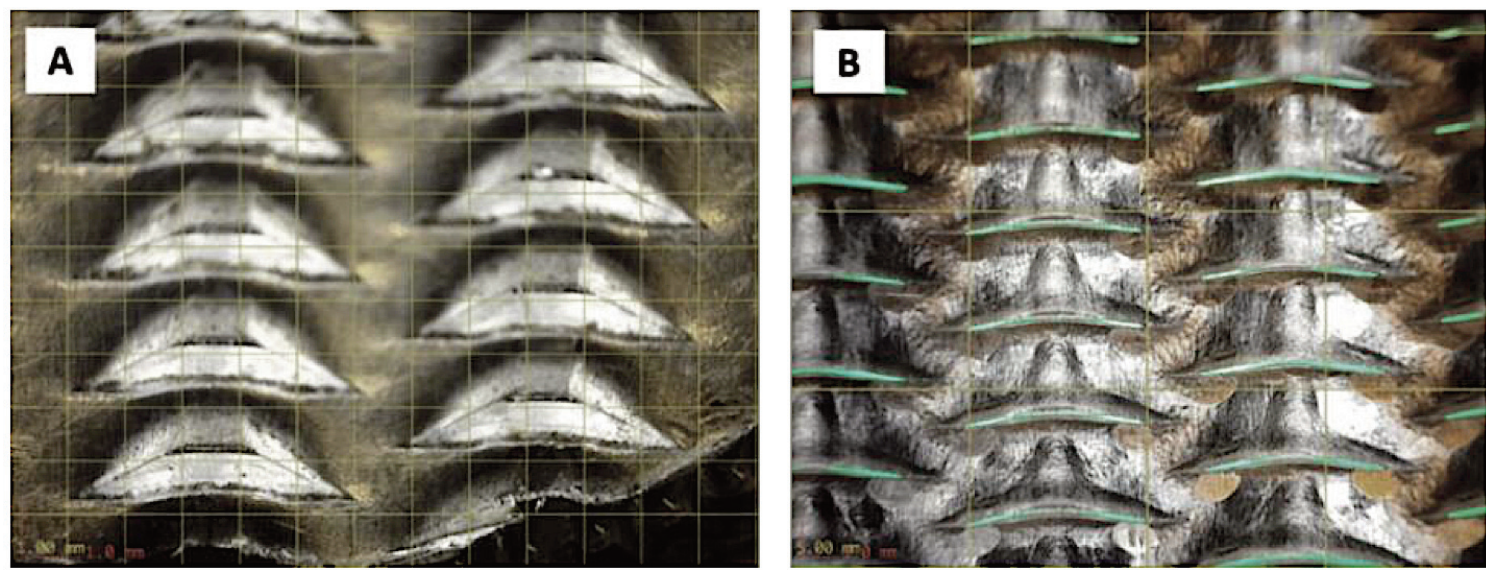

Fig. 2. Microscopy images revealing the aperture shape and size of materials A (left) and B (right).

B can also be produced of steel alloys (carbon or stainless steel), e.g., for implementation in high temperature environments.

\subsection{Impedance tube test}

One of the most important parameters in the characterization of noise attenuation performance is the acoustic absorption coefficient, the determination of which is discussed below.

The widely used method to determine the absorption coefficient of materials is the impedance tube method following ISO 10534-2:1998. The specimen size is hereby determined by the cross-sectional area of the test tube (see Fig. 2) [14].

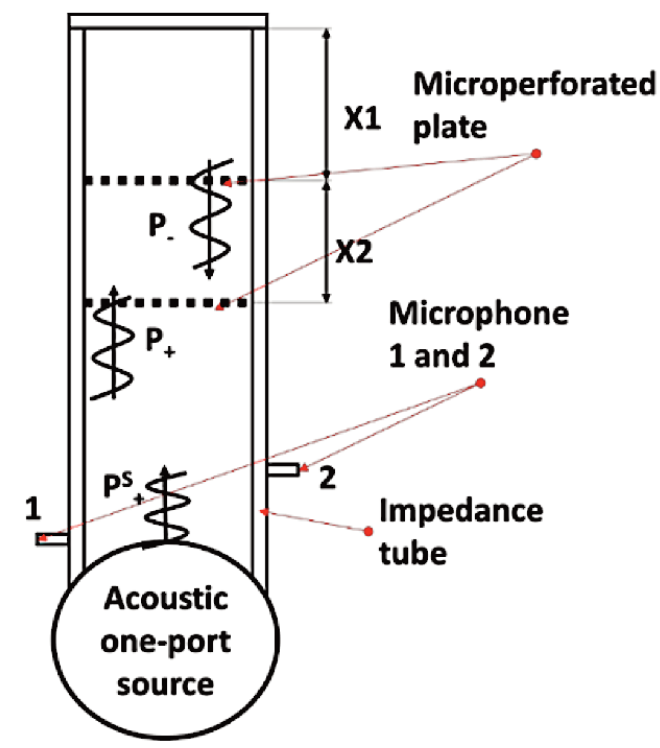

Fig. 3. One-port measurement set-up for the experimental determination of materials' absorption coefficient [15].
The material specimen is fitted into the rigidly closed end of the tube. By applying excitation noise from the electro-dynamic driver located at the end of the tube (see Figs 3 and 4) and by measuring the acoustic signals from two microphones, it is possible to calculate the absorption coefficient of the material tested. The plane wave acoustic pressures at the two microphones separated by distance $s$ can be expressed as follows [15]:

$$
\begin{aligned}
& p_{1}(f)=p_{1+}(f)+p_{1-}(f) \text { and } \\
& p_{2}(f)=p_{1+}(f) \exp \left(-i k_{+} s\right)+p_{1-}(f) \exp \left(i k_{-} s\right),
\end{aligned}
$$

where $p$ is the acoustic pressure, $f$ denotes the frequency, $k=2 \pi f / c$ is the wave number, $c$ represents the speed of sound, - and + denote the pressure waves propagating in

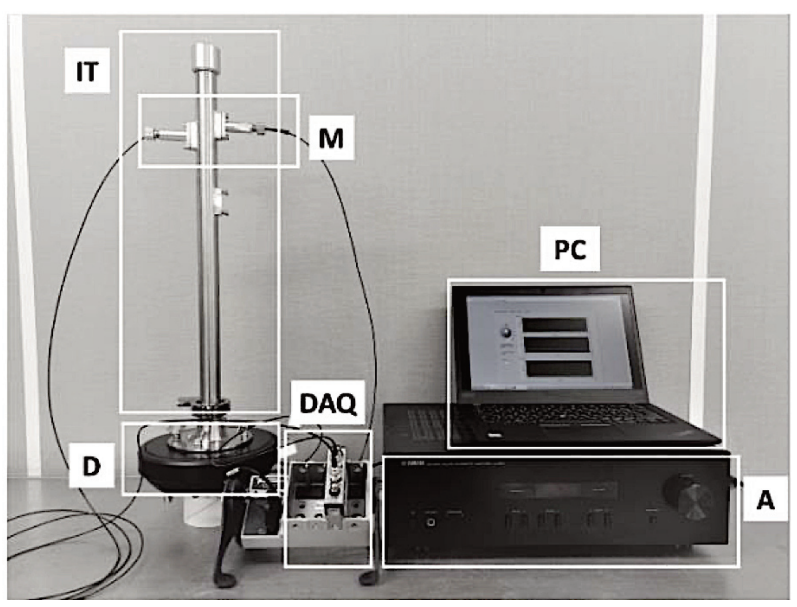

Fig. 4. One-port (impedance tube) test rig configuration: IT impedance tube (inner diameter $28 \mathrm{~mm}$ ); $\mathrm{M}$ - two 1/4" microphones; D - electro-dynamic drive (sound source); DAQ data acquisition system; PC - computer; A - excitation signal amplifier. 
negative and positive directions along the tube axis. The reflection coefficient at microphone 1 is defined as [15]

$$
R(f)=p_{1-}(f) / p_{1+}(f) .
$$

It can be shown that

$$
R(f)=\left(H_{12}^{e}-\exp \left(-i k_{+} s\right)\right) /\left(\exp \left(i k_{-} s\right)-H_{12}^{e}\right)
$$

where $H_{12}=p_{2} / p_{1}$ is the transfer function between induct mounted measurement microphones 1 and 2 . Then the absorption coefficient of the material is calculated as follows [15]:

$$
\propto_{s}(f)=|1-R(f)|^{2} .
$$

According to the impedance tube diameter of $28 \mathrm{~mm}$, the cut-of frequency is $8376 \mathrm{~Hz}$, and the observation range is chosen from $200 \ldots 8000 \mathrm{~Hz}$, which is determined by the microphone separation $(\mathrm{s}=16 \mathrm{~mm})$. In such experiments, the investigated material is placed onto the tube with varying distance from the back wall X1. Distance X1 was set from $0 \mathrm{~mm}$ to $50 \mathrm{~mm}$ with single-layer set-up (see Fig. 3). With double-layer set-up, two MPPs were placed in sequence with distances X1 and X2, where distance X1 was set to $30 \mathrm{~mm}$ and $50 \mathrm{~mm}$ and distance $\mathrm{X} 2$ was varying from $5 \mathrm{~mm}$ to $50 \mathrm{~mm}$. The experimental equipment and set-up are shown in Fig. 4. The experimental tests were carried out using the following equipment:

- two $1 / 4$ " prepolarized pressure microphones (G.R.A.S. 40BD),

- four-channel DAQ analyser (NI 9234) and USB Carrier (NI USB-9162),

- electro-dynamic driver (BMS 4591),

- excitation signal amplifier (Yamaha AS201).

\subsection{Transmission loss measurements for concept layouts}

In order to determine the noise reduction performance of the microperforated panels set up in a variety of layouts in silencer solutions, the transmission loss was measured by means of the dedicated two-port test facility (see Fig. 5). The transmission loss experiments were performed by using the following equipment:

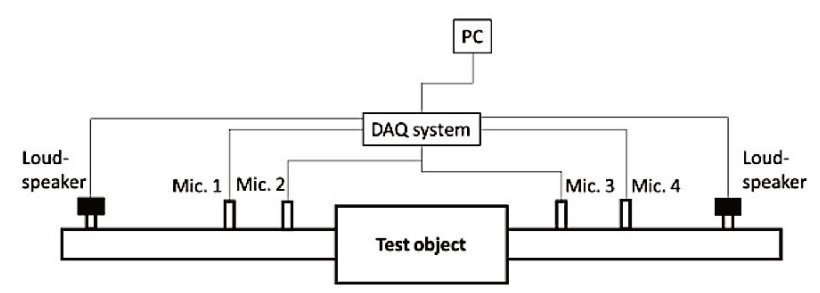

Fig. 5. Two-port measurement set-up for the determination of acoustic transmission loss.
- four $1 / 2$ " prepolarized pressure microphones (PCB ICP 010399),

- four-channel DAQ analyser (NI 9234),

- USB chassis (NI USB-9162),

- two electro-dynamic drivers (BMS 4591),

- signal amplifier (Yamaha AS201).

The transmission loss measurement is based on the 2-port method [16], where two electro-dynamic drivers are used as excitation sources and the relevant data is measured by four in-duct microphones (see Fig. 5). The measurement frequency range in this method is limited to $300 \ldots 1250 \mathrm{~Hz}$. The lower frequency is determined by the acoustic driver frequency limit, the upper frequency is limited by the cut-off frequency of the duct and by the microphone separations $s_{1}$ and $s_{2}(130 \mathrm{~mm})$. By using the determined 2-port data, the transmission loss is calculated by the following expression:

$$
T L=10 \log _{10}\left(\frac{1}{\left|S_{21}\right|^{2}}\right),
$$

where $S_{21}$ is $S$-matrix element describing the sound transmission through the test object [16-18].

The experiment was carried out for a variety of conceptual layouts, starting with the simple expansion chamber, and extending up to six chambers with equal spacing (see Fig. 6d). Different set-ups with microperforated elements, for example, inner tube (Fig. 6b) and concentrically placed double-layer inner tube (Fig. 6c) were also included, with double-layer separation distance set to $10 \mathrm{~mm}$. A noteworthy purpose was to design a fibreless silencer by the implementation of both the dissipative (primarily the double- and single-layered MPPs) and the reactive (the chambers) elements - performing as a hybrid solution.

\subsection{Determination of silencer insertion loss}

The acoustic performance of HVAC silencers is usually characterized by sound wave attenuation propagating along the test duct or radiating into the connected rever-
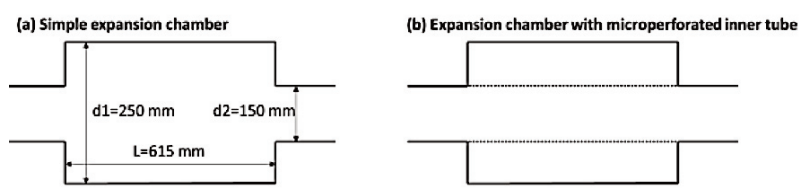

(c) Expo
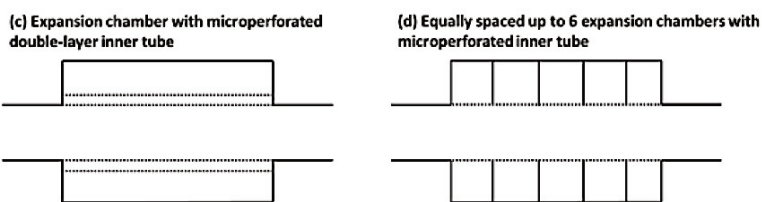

Fig. 6. Various silencer layout concepts used in the study. 
beration room (see Fig. 7), expressed in octave bands with central frequencies between 65 and $8000 \mathrm{~Hz}$ according to ISO 7235:2003 [19]. Since the 2-port method implemented for the transmission loss measurements described in the previous section was only used for the concept development purposes and covers only part of the frequency range under consideration, the noise attenuation was additionally determined by using the standard reverberation room approach. The test duct was connected to the sound source located inside the source room and discharged white noise into the second (receiving) room, via the ducted test object, see Fig. 7.

By assuming diffuse sound field in the room, the average sound pressure level was determined by the scanning microphone. The sound pressure level was determined in two cases: the duct without the silencer tested and the duct with the silencer installed. From the sound pressure values the sound power of the travelling wave inside the duct was determined. By this measurement technique, the insertion loss was calculated in octave bands. Due to the limited volume of the rooms in TalTech Acoustics Lab (source room $50 \mathrm{~m}^{3}$ and receiving room $66 \mathrm{~m}^{3}$ ), the frequency range measured was limited to $125 \ldots 8000 \mathrm{~Hz}$. Since it is known that at small flow speeds characteristic to the operation of HVAC silencers the attenuation does not remarkably depend on the flow speed, no mean flow was applied in experiments. The experimental equipment included:

- 2-channel noise level meter Brüel \& Kjær 2270,

- condenser microphones Brüel \& Kjær 4189,

- scanning microphone boom Brüel \& Kjær 3923,

- calibrator Brüel \& Kjær 4231.

According to standard ISO 7235:2003, the insertion loss (IL) was calculated as follows:

$$
I L=L_{W I I}-L_{W I}
$$

where $L_{W I}$ is the sound power level propagating along the test duct and radiating into the reverberation room when the test object is installed and $L_{W I I}$ is the sound power level, radiating into the reverberation room while the substitution duct replaces the test object [19].

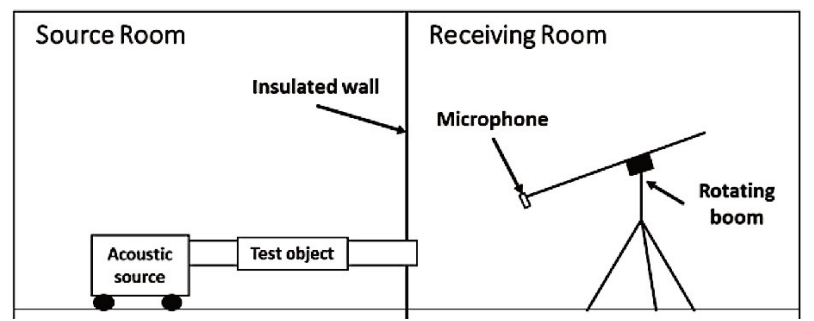

Fig. 7. Reverberation Room's test set-up at TalTech Acoustics Lab designed for the determination of acoustic insertion loss.

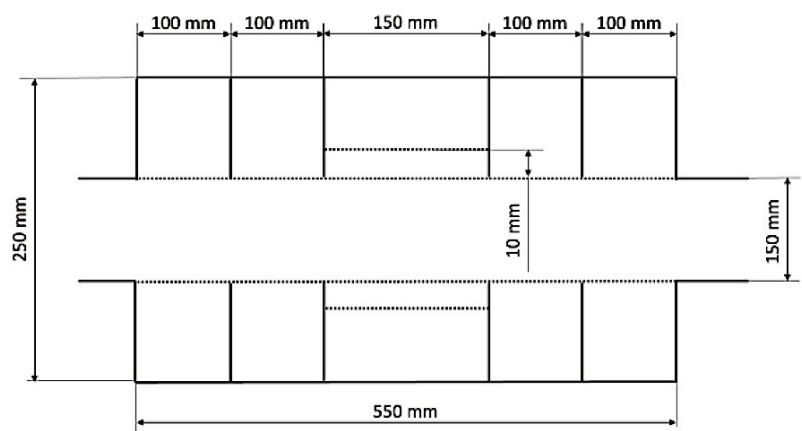

Fig. 8. A concept layout incorporating 5 expansion chambers and a microperforated inner tube and double-layer microperforated central chamber section.

By considering the test results, the final concept layout was chosen and is presented in Fig. 8.

\section{RESULTS}

The absorption coefficient was initially measured for each microperforated panel by varying distance X1 from the back wall (from $0 \mathrm{~mm}$ to $50 \mathrm{~mm}$, see Fig. 3). The tests were repeated for all three different material samples shown in Fig. 1. The comparison results from the impedance tube test are presented in Fig. 9, where distance X1 was set to $15 \mathrm{~mm}$ from the rigid enclosure. It can be clearly seen that materials $\mathrm{A}$ and $\mathrm{B}$ exhibit higher absorption characteristic than material $\mathrm{C}$.

In Figs 10 and 11 it can be observed that by increasing the distance from the back wall, the absorption peak will be shifted towards the lower frequencies. The initial back wall distance was set to $0 \mathrm{~mm}$, as the perforated plate was at the far end of the test tube. In this case the maximum absorption coefficient occurs at $3600 \mathrm{~Hz}$. With distance

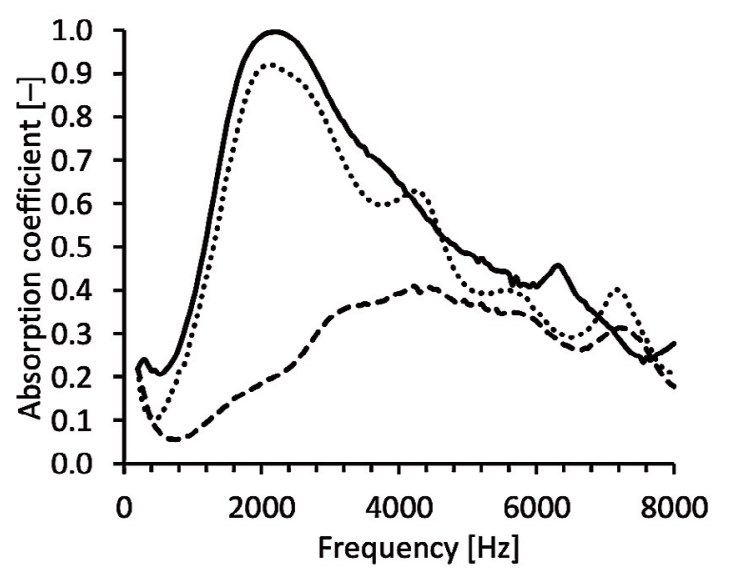

Fig. 9. Absorption coefficient for materials A (dotted line), B (solid line) and $\mathrm{C}$ (dashed line) with distance $\mathrm{X} 1$ set to $15 \mathrm{~mm}$. 


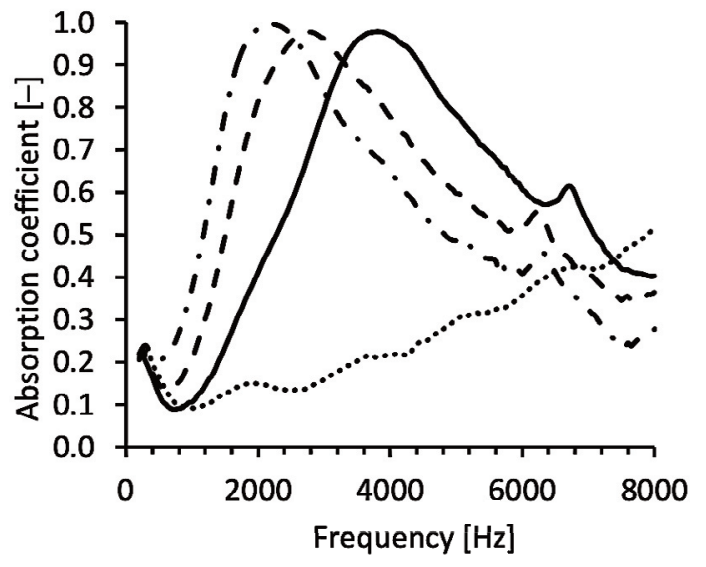

Fig. 10. Absorption coefficient for one microperforated plate (material A), distance X1 was set from $0 \mathrm{~mm}$ (dotted line) to $15 \mathrm{~mm}$ (dash-dotted line).

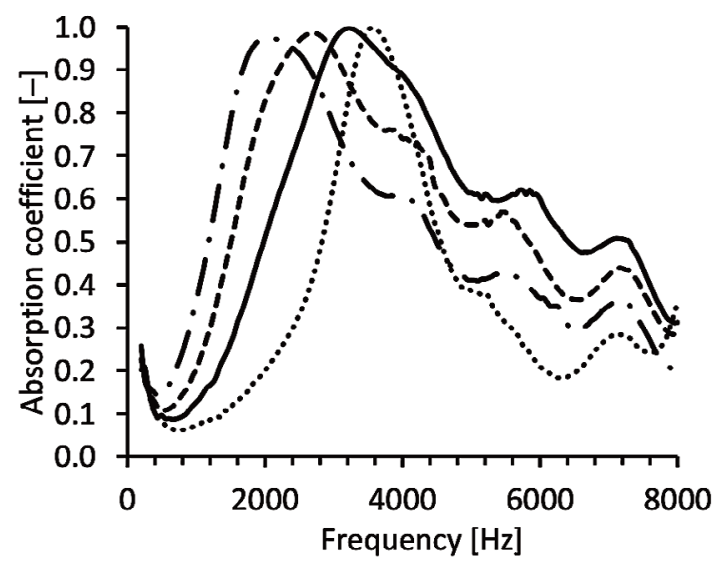

Fig. 11. Absorption coefficient for one microperforated plate (material B), distance X1 was set from $0 \mathrm{~mm}$ (dotted line) to $15 \mathrm{~mm}$ (dash-dotted line).

$\mathrm{X} 1$ set to $15 \mathrm{~mm}$, the maximum absorption shifts to around $2100 \mathrm{~Hz}$

For a single-layer set-up of material $\mathrm{C}$, the results are presented in Fig. 12. Here distance X1 was varied between 0 and $15 \mathrm{~mm}$. Consequently, we can observe remarkably lower absorption performance with higher porosity figures (18\% respectively).

Subsequently, two extreme cases were tested, distance $\mathrm{X} 1$ was first set to $30 \mathrm{~mm}$, and then to $50 \mathrm{~mm}$. The respective results are shown in Fig. 13. We can observe that the maximum absorption shifts even more towards the lower frequencies $(1200 \mathrm{~Hz}$ and $900 \mathrm{~Hz}$ respectively). Also, it can be seen that the second peak appears at higher frequencies with the distance set to $30 \mathrm{~mm}$. By fixing X1 to $50 \mathrm{~mm}$, a third absorption peak additionally appears in the frequency range studied.

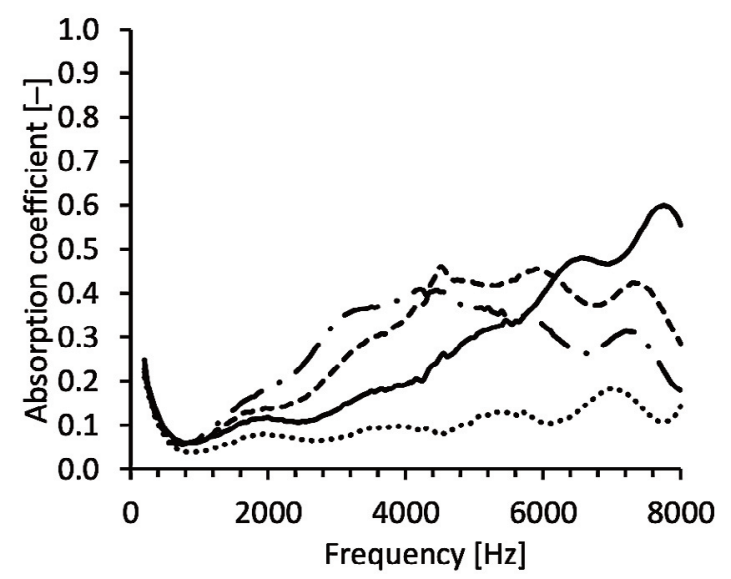

Fig. 12. Absorption coefficient for one microperforated plate (material C), distance X1 was set from $0 \mathrm{~mm}$ (dotted line) to $15 \mathrm{~mm}$ (dash-dotted line).

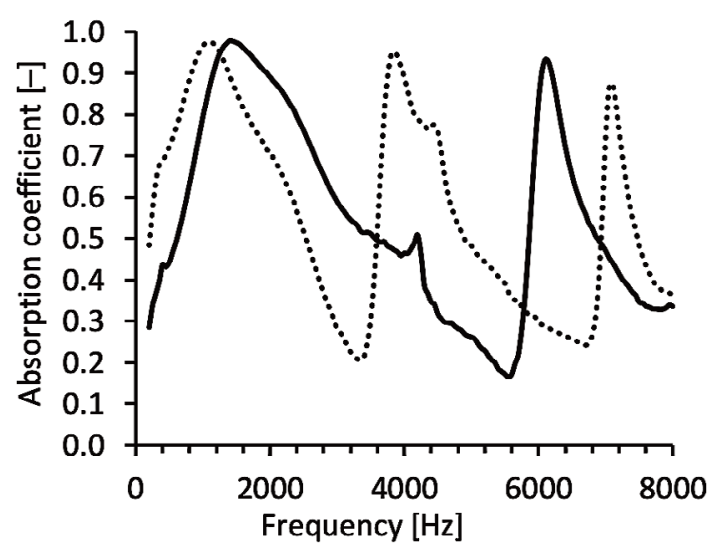

Fig. 13. Absorption coefficient for material $\mathrm{B}$, distance $\mathrm{X} 1$ was set to $30 \mathrm{~mm}$ (solid line) and to $50 \mathrm{~mm}$ (dotted line).

Secondly, the double-layer set-up test was conducted with materials A and B. Distance X1 was set to $30 \mathrm{~mm}$ and held constant. The varying parameter here was distance X2, for which the absorption coefficient results are shown in Figs 14 and 15.

The first absorption peak shifts even more to the lower frequencies, appearing at around $900 \mathrm{~Hz}$. As the frequency for a single-panel maximum absorption was $1200 \mathrm{~Hz}$ with the distance of $30 \mathrm{~mm}$, and $900 \mathrm{~Hz}$ with the distance of $50 \mathrm{~mm}$, we can conclude that with the double-layer setup the overall distance $(\mathrm{X} 1+\mathrm{X} 2)$ appears to also play a key role in the silencing performance. The result for material $\mathrm{B}$ is presented in Fig. 15, where even better sound absorption performance can be observed within a much wider frequency range.

Subsequently, the results obtained from the two-port test are presented and discussed below. The transmission 


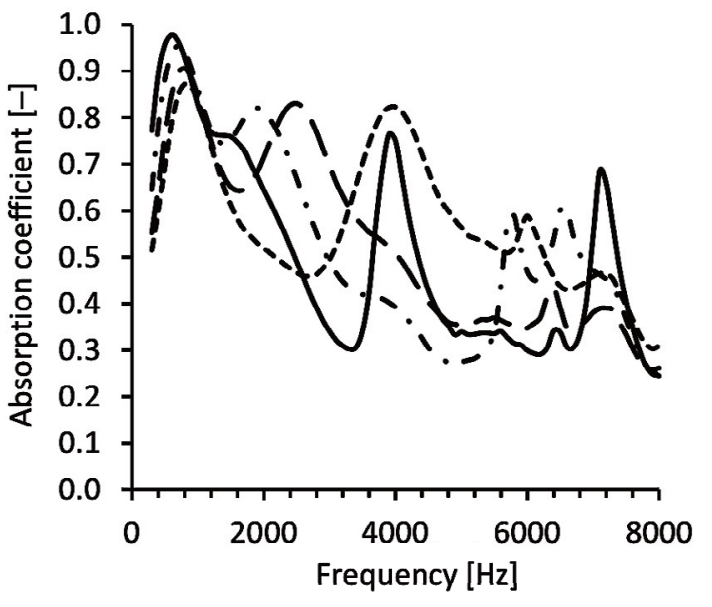

Fig. 14. Double-layer set-up for material A. Distance X1 was set to $30 \mathrm{~mm}$ and distance $\mathrm{X} 2$ was varied from $5 \mathrm{~mm}$ (dashed line) to $50 \mathrm{~mm}$ (solid line).

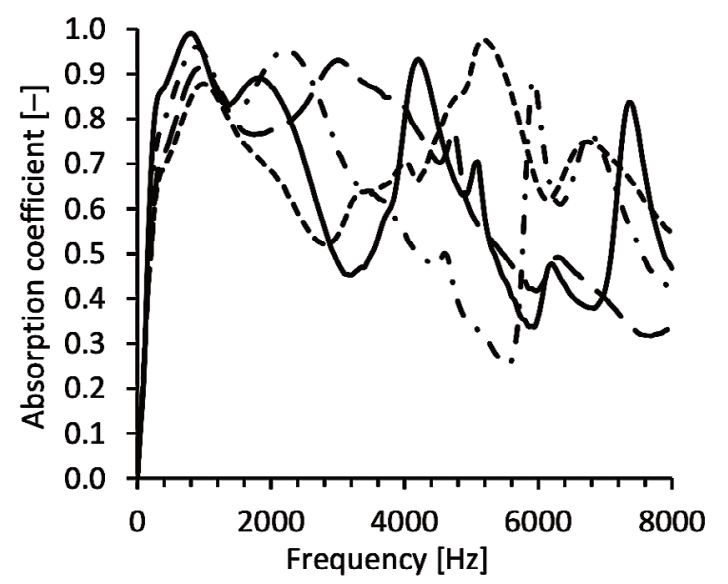

Fig. 15. For double-layer set-up for material B, distance X1 was set to $30 \mathrm{~mm}$ and distance X2 was varied from $5 \mathrm{~mm}$ (dashed line) to $50 \mathrm{~mm}$ (solid line).

loss for two different basic noise control layouts is illustrated in Fig. 6a and 6b, where the first represents a single expansion chamber (purely reactive layout) and the second a single expansion chamber with added microperforated inner tube (also introducing the dissipative effect from the MPP), respectively.

As demonstrated in Fig. 16, the single expansion chamber offers low sound attenuation, averaging from 2.5 to $3 \mathrm{~dB}$, but being constant through the frequency range. Adding a microperforated inner tube, we accomplish higher sound absorption (ca $2 \times$ higher) and improvement increases with higher frequencies, which is common with absorbed materials. It should be emphasized that by exploiting the reactive and the dissipative effect as combined, we gain more sound control performance compared

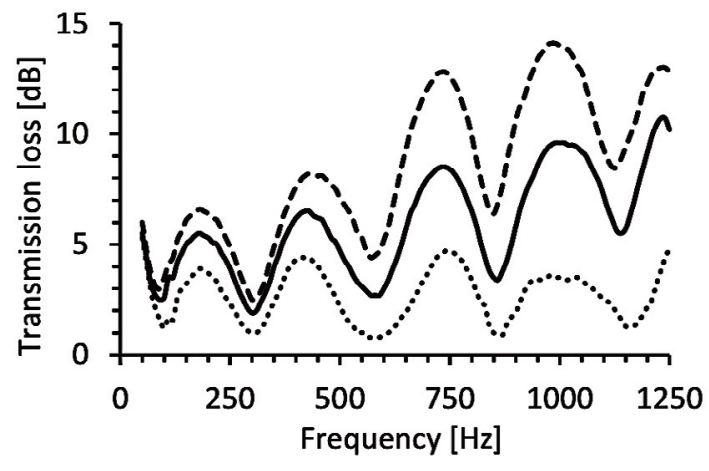

Fig. 16. Transmission loss comparison for single expansion chamber (dotted line) and with added microperforated inner tube (solid line). Double-layer concentrically placed inner tube (dashed line) with separation distance set to $10 \mathrm{~mm}$ shows even more potential.

to their separate use. Moreover, it is evident that by using a double-layer concentrically placed microperforated inner tube (distance between layers was set to $10 \mathrm{~mm}$, see Fig. 6c), we can even further increase the acoustical performance.

Secondly, to explore more reactive type solutions, multiple expansion chamber versions were tested. The results are presented in Fig. 17. Considering the fact that the main dimensions of the silencer were kept constant, increasing the number of chambers means that the individual chamber size will decrease (see Fig. 6d).

From the transmission loss measurement it appears that by increasing the number of expansion chambers, the noise level reduction clearly improves. However, the peak value shifts toward higher frequency, which is natural considering the wavelength-dependent reactive effects taking place in the chambers. The secondary effect caused by the additive reactive influence from the equally dimensioned chambers increases the acoustic transmission loss even more.

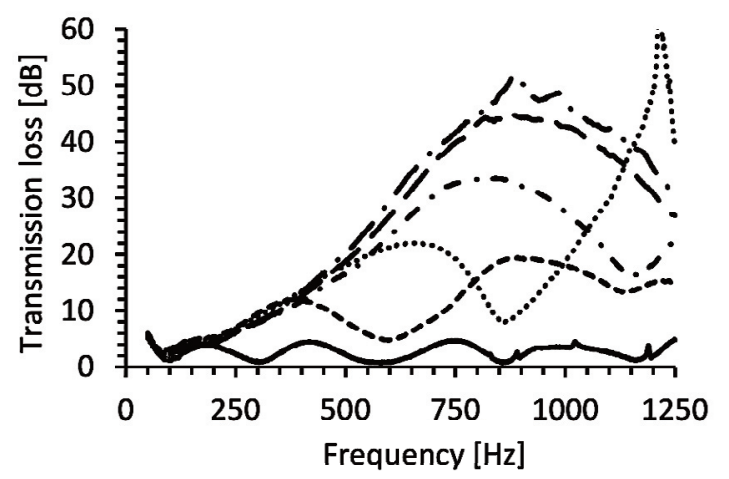

Fig. 17. Transmission loss measurements with up to 6 expansion chambers. 1 chamber (solid line) and 6 chambers (long dashdotted line) (see Fig. 6d). 


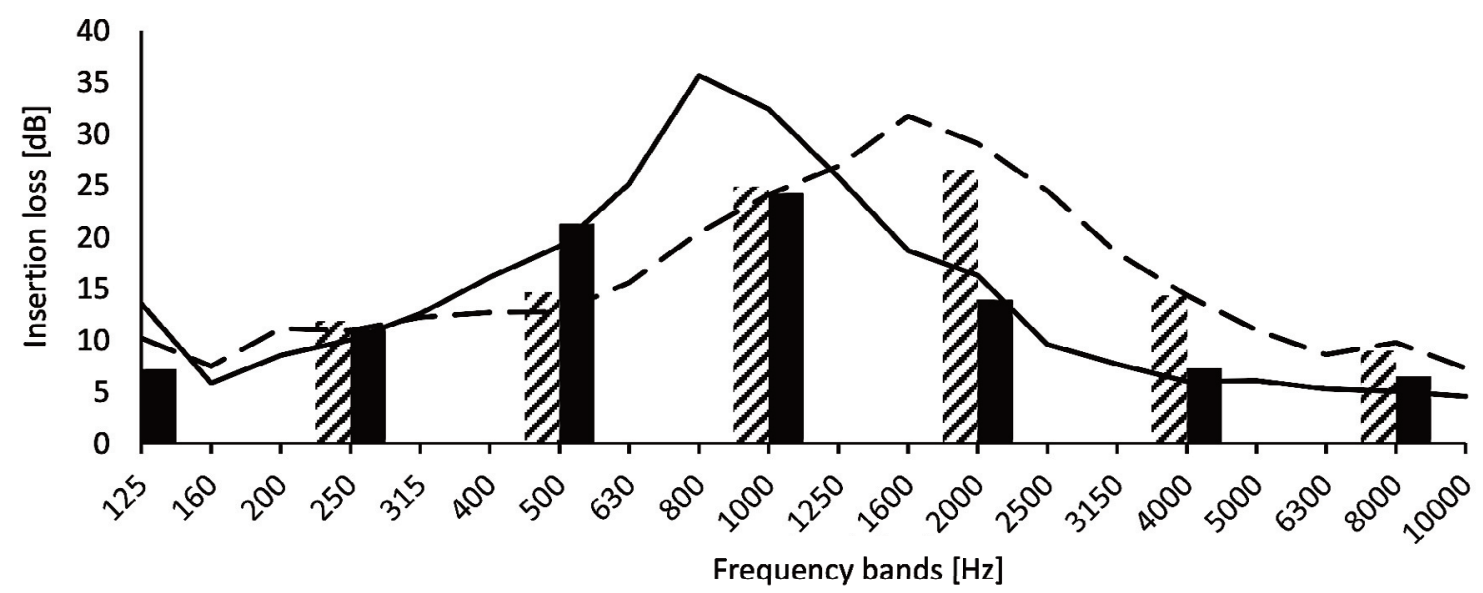

Fig. 19. Insertion loss of the silencer prototype in $1 / 1$ octave band (lines) and in $1 / 3$ octave band (vertical columns) compared to the average of commercially available HVAC silencer selected for reference. Insertion loss of the proposed silencer prototype (solid line, black columns) compared with the reference units (dashed line, hatched columns).

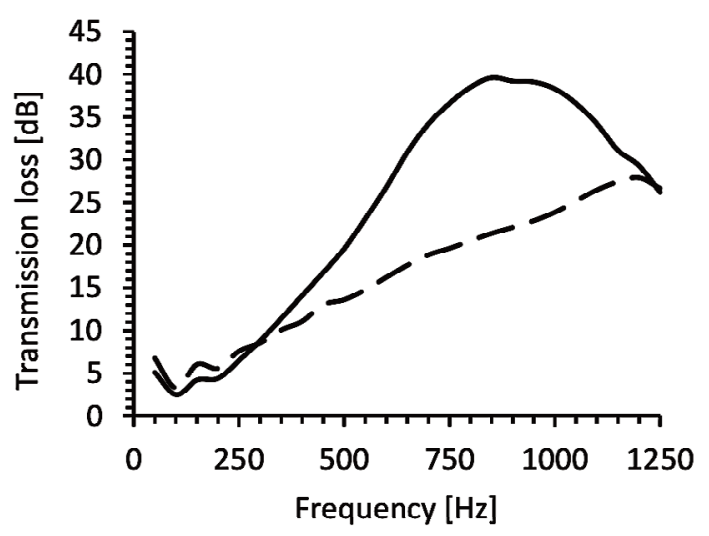

Fig. 18. Transmission loss measured for the proposed layout and compared with a market average.

As for the final test, the hybrid solution was selected with five sequential expansion chambers, also incorporating the double-layer microperforated inner tube inside the middle section (see Fig. 8). For comparison, the commercially available market average HVAC silencer was also measured, which had a single expansion chamber with fibrous material filament and microperforated inner tube (see Fig. 6b) [20]. From the tests conducted, we can conclude that the proposed solution outperforms the fibrous material-based solutions commercially available. And most notably, its characteristics are superior in the lower frequency range where it is primarily important (see Fig. 18).

From the insertion loss results (Fig. 19), we can observe the acoustic performance of the solution in a considerably wider frequency range between $125 \ldots 10000 \mathrm{~Hz}$. In comparison with the average data of commercially available HVAC silencers, it can be seen that the proposed unit performs better regarding the absolute sound attenuation level (around $5 \mathrm{~dB}$ higher) than the reference silencers. Furthermore, it outperforms in the lower frequency range, in which the dominant HVAC system noise emotion is expected.

\section{CONCLUSIONS}

Sound absorption properties of three fibreless microperforated sheet metal panels in a variety of single- and double-layer configurations were experimentally studied in this paper. The results exhibit the multi-layered material's suitability for sustainable noise control applications. A variety of conceptual layouts of silencer solutions were studied and the most effective solution has been presented.

The proposed HVAC silencer layout incorporates a hybrid, reactive and resistive noise control solution, composed of five sequential expansion chambers, and a microperforated inner tube with innovative double-layer middle section. The sustainable prototype has been developed and tested in comparison with a market average of commercially available fibrous material filled silencers, demonstrating significant noise control capabilities with adaptiveness for a targeted frequency range.

\section{ACKNOWLEDGEMENTS}

This research was supported by the Estonian Research Council grant EAG28 "Smart micro-perforated silencer for heat, ventilation, and air conditioning systems". The publication costs of this article were covered by the Estonian Academy of Sciences and Tallinn University of Technology. 


\section{REFERENCES}

1. Maa, D. Y. Theory and design of microperforated panel sound-absorbing constructions. Sci. Sin., 1975, 18(1), 55-71.

2. Maa, D. Y. Microperforated-panel wideband absorbers. Noise Control Eng. J., 1987, 29(3), 77-84.

3. Maa, D. Y. Potential of microperforated panel absorber. $J$. Acoust. Soc. Am., 1998, 104(5), 2861-2866.

4. Kabral, R., Rämmal, H., Lavrentjev, J. and Auriemma, F. Acoustic studies on small engine silencer elements. SAE Technical Paper 2011-32-0514, 2011.

5. Lavrentjev, J. and Rämmal, H. On experimental techniques to determine acoustic performance of small exhaust silencers. SAE Technical Paper 2009-32-0015, 2009.

6. Kabral, R., Rämmal, H., Auriemma, F., Luppin, J., Kõiv, R., Tiikoja, H. and Lavrentjev, J. A novel design for cruiser type motorcycle silencer based on micro-perforated elements. SAE Technical Paper 2012-32-0109, 2012.

7. Auriemma, F., Rämmal, H. and Lavrentjev, J. Microgrooved elements - a novel solution for noise control. $S A E$ Int. J. Mater. Manuf., 2013, 6(3), 599-610.

8. Rämmal, H. and Lavrentjev, J. Endurance of microperforated elements in unmanned ground vechicle's small diesel engine silencer application. SAE Technical Paper 2019-32-9533, 2019.

9. Rämmal, H. and Lavrentjev, J. Reliability study of microperforated elements in small engine silencer application. SAE Technical Paper 2017-32-0075, 2017.

10. Sakagami, K., Yairi, M. and Morimoto, M. Multiple-leaf sound absorbers with microperforated panels: An overview. Acoust. Aust., 2010, 38(2), 76-81.
11. Sack, S. and Åbom, M., Modal filters for mitigation of induct sound. Proc. Meet. Acoust., 2016, 29, 040004. https://doi.org/10.1121/2.0000473

12. Allam, S. and Åbom, M. Fan noise control using microperforated splitter silencers. J. Vib. Acoust., 2014, 136(3), 031017. https://doi.org/10.1115/1.4027245

13. www.sontech.se

14. ISO 10534-2:1998. Acoustics - Determination of sound absorption coefficient and impedance in impedance tubes Part 2: Transfer-function method.

15. Lavrentjev, J. and Rämmal, H. Experimental study of noise barrier boards with increased acoustic performance by utilizing Helmholtz resonator effects. Mater. Today: Proc., 2020, 28(4), 2566-2571.

16. Rämmal, H., Åbom, M., Tiikoja, H. and Bodén, H. Experimental facility for the complete determination of sound transmission in turbochargers. SAE Technical Paper 2010-01-1424, 2010. https://doi.org/10.4271/2010-01-1424

17. Lavrentjev, J. Multi-port models for source characterization of fluid machines. PhD thesis. Royal Institute of Technology, Stockholm, Sweden, 1998.

18. Lavrentjev, J., Rämmal, H. and Tiikoja, H. The passive acoustic effect of automotive catalytic converters. SAE Technical Paper 2011-24-0219, 2011.

19. ISO 7235:2003. Acoustics - Laboratory measurement procedures for ducted silencers and air-terminal units Insertion loss, flow noise and total pressure loss.

20. Villau, M., Rämmal, H. and Lavrentjev, J. Innovative fibreless HVAC duct silencer based on microperforated elements. Mater. Today: Proc., 2021, 47, 3154.

\title{
Mikroperforeeritud elementidel põhinev jätkusuutliku müra vähendamise kontseptsiooniuuring ventilatsioonisüsteemides
}

\author{
Margus Villau, Hans Rämmal ja Jüri Lavrentjev
}

Viimasel ajal on jätkusuutlike ja keskkonnasõbralike summutite kujundamisel trendiks muutunud kiudmaterjalita lahendused. Artiklis on tõestatud, et mikroperforeeritud paneelid pakuvad piisavat jõudlust kiudmaterjalide kihtide asendamiseks, mida tavaliselt kasutatakse masstoodangu summutites. Käesolevas artiklis on esitatud mikroperforeeritud elementide akustiline uuring, mille eesmärk on saavutada tõhusad ja keskkonnasõbralikud müra ohjamise lahendused. Heli neeldumisteguri maksimeerimiseks oodatavas töösageduse vahemikus on eksperimentaalselt katsetatud mitut mikroperforeeritud lehtmetallist paneeli eri konfiguratsioonides. Optimaalsed lahendused on rakendatud selles uuringus ja esitatud uudsete lahenduste kujundamisel. Neid on võrreldud tavapäraste kiudmaterjalidega täidetud summutitega, mis on kaubanduslikult saadaval. Uuringu tulemused näitavad summuti rakendamiseks kahekihiliste mikroperforeeritud paneelide sobivust, mille eesmärk on müra intensiivne neeldumine. 